\title{
緑藻ヘマトコッカスによるアスタキサンチンの生産とその利用
}

\section{Astaxanthin: commercial production and its potential health-promoting effects}

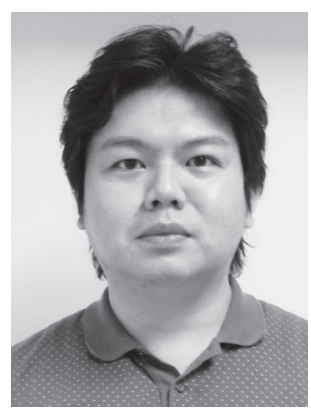

西田 康宏

アスタリール株式会社研究開発部

† 930-0397

富山県中新川郡上市町横法音寺 55

Yasuhiro Nishida

Research \& Development Division, AstaReal

Co., Ltd.

55 Yokohoonji Kamiichimachi, Nakaniikawagun,

Toyama 930-0397, Japan

論文要旨：アスタキサンチンとは, 自然界において甲殼類, 魚類, 鳥類などの幅広い生物に認められるカ ロテノイドに属する美しい赤橙色を示す色素である。従来からアスタキサンチンは魚類・家禽の色揚げ剤と して養殖産業で利用されてきたが，1980 年代後半からアスタキサンチンの優れた脂質過酸化抑制作用，一 重項酸素消去能が報告され，1990 年代初めにへマトコッカス藻を用いた大量培養による天然物由来による アスタキサンチンの商業生産方法が確立されて以降, ヒト用途への利用が期待されるようになり, アスタキ サンチンの生理活性などが盛んに研究されるようになった。その結果, 多くの有用な機能性が見出され, サ プリメントなどの機能性食品や化粧品等, 多岐にわたる用途に使用されつつある。本稿では, 微細藻類であ るへマトコッカス藻によるアスタキサンチンの生産やアスタキサンチンの有用性の一つとして挙げられる, メタボリックシンドロームなど生活習慣病や代謝に与える影響について紹介したい。

\begin{abstract}
Astaxantin is a naturally occurred orange-red pigment in a wide variety of living organisms such as microalgae, yeast, salmon, trout, crayfish and crustaceans. Classically astaxanthin have been commercially used as feed additives to improve the pigmentation in aquaculture and poultry industries. In addition to its role as a pigment, astaxanthin may efficiently work biological antioxidant in vivo. Recently it has been reported its potent biological actions, such as antioxidative activity, anti-diabetic, anti-inflammatory actions, immunomodulatory and anticancer activity. Thus, in the1990s, there has been significant commercial interest in developing cultivation of unicellular green algae named Haematococcus as a promised source of astaxanthin used for food industry. The aim of this review, a summary of industrial production of astaxanthin by Heamatococcus algae and the potent biological activity of astaxanthin, was to provide a further understanding of the beneficial health effects of astaxanthin.
\end{abstract}

Key words: Astaxanthin, carotenoids, antioxidants, Hematococcus, green algae, metabolic syndrome, obesity, diabetes

\section{1 アスタキサンチンとは}

アスタキサンチン (Astaxanthin, IUPAC 名 : 3,3' -dihydroxy- $\beta, \beta$-carotene-4,4' -dione, CAS\# : 472-61-7,

Fig. 1）とは，ノーベル化学賞で著名な Prof. Richard Kuhn が 1938 年にロブスターから単離した美しい赤橙

連絡者：西田康宏

E-mail : y-nishida@astareal.co.jp
色を示す色素 ${ }^{1)}$ で, 炭素数 40 からなり，イソプレノイ ド（テルペノイド）のカロテノイドと呼ばれる脂溶性色 素群に属する。カロテノイドは, 自然界に広く分布し, $\beta$-カロテン, リコペン, ルテインなどがよく知られて いる。カロテノイドを更に細分化すると, $\beta$-カロテン やリコペンのような分子が炭素および水素原子のみで構 成されるカロテンと, ルテインやアスタキサンチンなど のような酸素原子をその分子内に持つキサントフィルに 

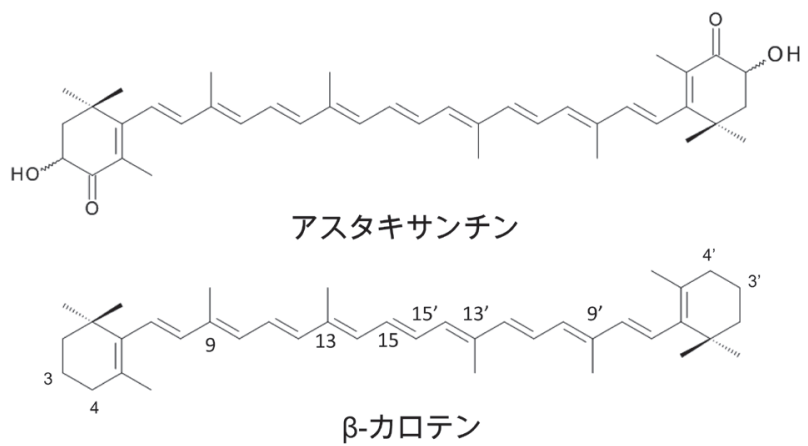

Fig. 1 アスタキサンチンの化学構造

分けられる。

自然界ではアスタキサンチンは，エビ，カニなどの甲 殼類, タイやマスなどの体表, サケなどマス科硬骨魚類 の筋肉中に認められ，我々日本人にとっては日常的に食 する魚介で見ることができる非常になじみ深い“色”で ある。それ以外にも軟体動物, 棘皮動物, 腔腸動物, 節 足動物, 原索動物など多岐にわたる動物の体表や内臓, 卵などに分布し，さらには，鳥類や爬虫類，両生類の皮 膚や体毛，網膜にも分布しており，含有する生物種は動 物を中心に非常に多い。余談だが, 高等動物は, カロテ ノイドを de novo 合成できないため, 多くは食物連鎖で アスタキサンチンそのものを摂取し蓄積するか，その他 のカロテノイドを体内で代謝変換していると考えられて いる ${ }^{2,3)}$ 。微生物界では， $\alpha$ - プロテオバクテリアを中心 に海洋性細菌で多く認められ，真菌では，異型担子菌酵 母である Xanthophyllomyces dendrorhous（パフィア酵 母として知られている）が生合成する。

一方, 植物界では, すべての光合成植物がキサントフィ ルを産生するにも関わらず，アスタキサンチンを生合成 する生物はごく一部に限られる。高等植物においては, キンポウゲ科の Adonis 属の一部の花弁に含まれるほか は, Haematococcus 属を中心とする単細胞の緑藻植物が, 環境耐性に特化した非常に強固な休眠細胞を形成すると きに見られるのみである。

アスタキサンチンの化学的構造として, 長いポリエン 鎖による共役二重結合系の両端に $\beta$-ionone 環を有する $\beta$ - カロテンと同様の骨格を示すが, 通常の栄養条件下 ではプロビタミン A 活性はない。特徵的なのは, 両端 の環の 3 位に水酸基が，4位にケト基といった極性基を 有することである（Fig. 1)。

C3 位は不斉炭素であるため, 水酸基の向きによって 3 つの光学異性体を有し, 生物によっては C3 位の水酸 基に中〜長鎖の脂肪酸が結合したアスタキサンチンエス テルを形成している。ヒトが摂食した場合は，消化吸収 の過程でアスタキサンチンエステルの脂肪酸が外れ, 血
液から検出されるアスタキサンチン自身はほとんどフ リー体として存在することが知られている。また, 共役 系の二重結合は, 通常はtrans 型をとるものが多いが, 9 位，13 位，15 位あるいはこれらの複数個所で cis 配置 を取る幾何異性体も存在する。

アスタキサンチンの従来からの用途として, 魚類, 家 禽の卵などの色揚げ剤として養殖産業での利用が挙げら れるが, 1990 年代初めにへマトコッカス藻を用いた大 量培養による天然物由来によるアスタキサンチンの商業 生産方法が確立されて以降, アスタキサンチンの生理活 性などが盛んに研究されるようになり，優れた抗酸化作 用をはじめ，多くの有用な機能性が見出されてきたこと から, サプリメントやその機能性を付加した食品添加物 などの用途を中心に天然由来のアスタキサンチンの需要 が急速に増大しつつある。サプリメントや食品添加物の 用途で利用されるアスタキサンチンはへマトコッカス藻 由来のものが主流であり, 培養により世界各地で商業的 に生産されている。参考までに自然界および産業的に用 いられる生物種のアスタキサンチン含量については以

下，Table 1 にまとめた。

\section{2 ヘマトコッカス藻によるアスタキサンチン生産}

ヘマトコッカス藻は, 緑藻に属する淡水性の単細胞の 微細藻類で，世界中の湖沼などで認めることができる。 環境ストレスがあると，アスタキサンチンを細胞中へ蓄 積し，その含量は，Table 1 に示したように他の生物と 比較して段違いに高い。また，素材としての安全性につ いても多くのデータの蓄積があり, ヒト用途の原料とし ては，それらから考えると最適であろう。

ヘマトコッカス藻の生活史（ライフサイクル）は非常 にユニークで，通常，好適な環境下では緑色で光合成を 行ないながら活発に分裂・増殖する。しかしながら, 環 境が変化し，たとえば，栄養分が不足し飢餓状態になる， あるいは, 強い光に暴露される, 乾燥するなどして生育 に適さない環境下におかれた場合，細胞壁を肥厚化し， 細胞の形質を変化させ，細胞内に大量の脂質とともに自

Table 1 一般的な食品などに含まれるア スタキサンチン含量 $(\mathrm{mg} / \mathrm{kg})$

\begin{tabular}{lr}
\hline & 含有量 $(\mathrm{mg} / \mathrm{kg})$ \\
\hline イクラ & $0-14$ \\
鮭 & $3-40$ \\
ニジマス & $1-13$ \\
オキアミ & $45-130$ \\
エビ・カニ & -400 \\
ファフィア酵母 & $30-8,000$ \\
ヘマトコッカス藻 & $10,000-80,000$ \\
\hline
\end{tabular}


己防御のためにアスタキサンチンを溜め込み休眠状態の シスト様細胞に変化する。やがてまた，環境が良好にな ると緑色の栄養細胞に戻り, 再度増殖を開始する。この 耐久性シストは, 非常に頑強で保存性がよく, たとえば, 数年間放置したシストでさえ，栄養状態がよくなると再 度分裂を開始する（Fig. 2)。

これら特徵を利用したへマトコッカス藻の大量培養に よって天然アスタキサンチンの効率的な生産が行われて いる。ヘマトコッカス藻の商業的生産風景を Fig. 3 に示 した。

富士化学工業グループの AstaReal 社では, 1994 年に ヘマトコッカス藻の大量培養を利用したアスタキサンチ ンの生産に成功し，世界に先駆けて商業規模での生産を

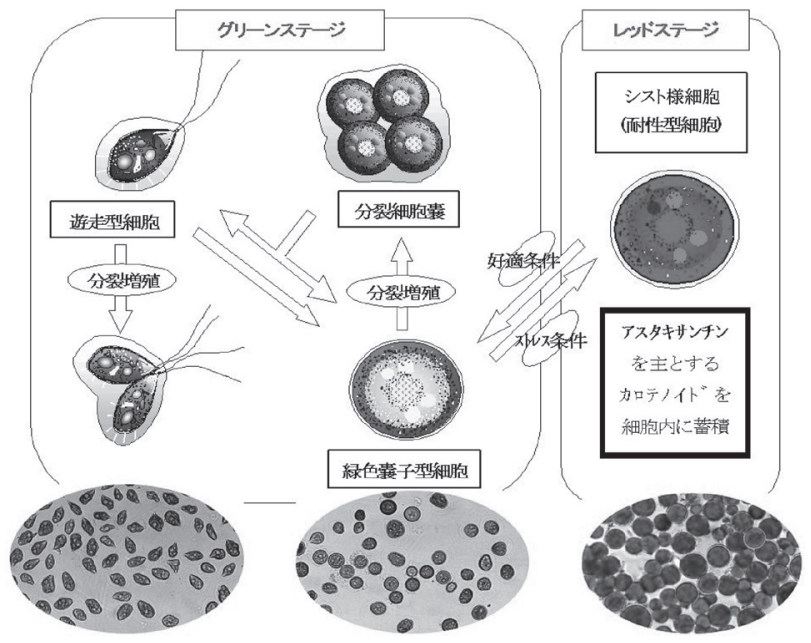

Fig. 2 ヘマトコッカス藻の生活史

(A)

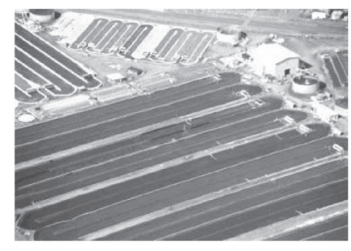

(B)
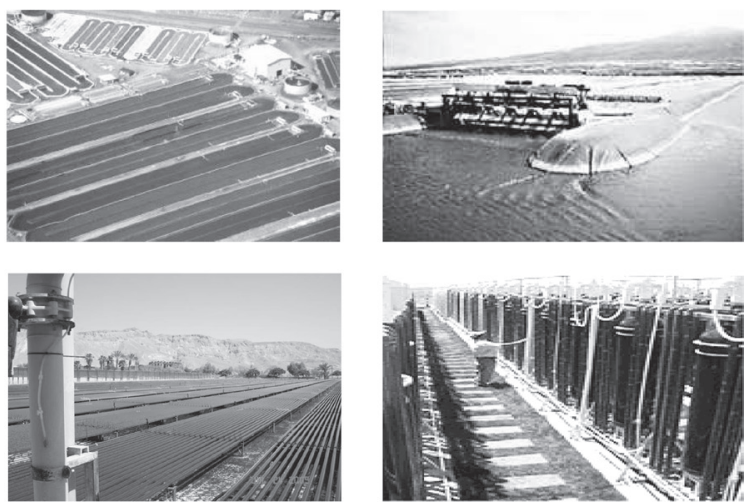

(C)
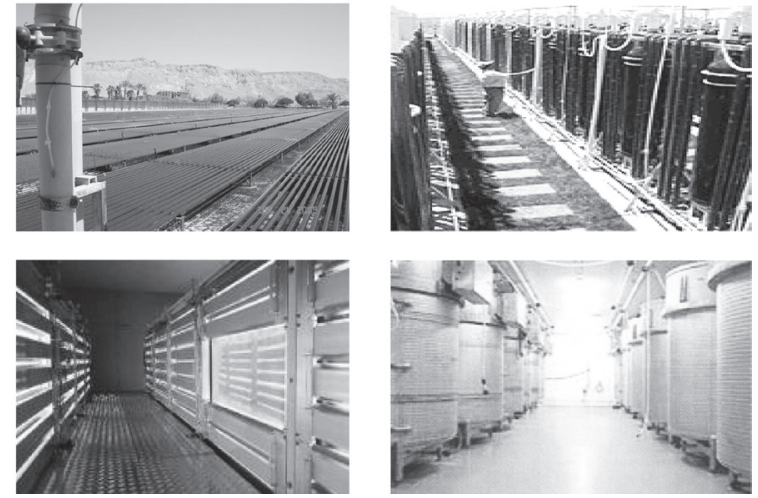

Fig. 3 ヘマトコッカス藻の商業的培養 屋外解放系方式（オープンポンド）(A)。屋外閉鎖系方式 (チューブラー) $(\mathrm{B})$ 。屋内閉鎖系方式 $(\mathrm{C})$ 。
開始した。藻類の培養は太陽光を利用するため, オープ ンポンドやチューブラー様の培養設備を用いて, 屋外で なされるのが一般的であるが, ヘマトコッカス藻は微細 藻類の中でも環境要因に敏感で, 日々変動する屋外の自 然条件を最適な製造環境に維持することは容易ではない 上に, 細胞増殖も他の微細藻と比較し緩慢であるため, 外部から混入する異種藻類との競争に弱く, 屋外の培養 では安定した品質のへマトコッカス藻をコンスタントに 生産することは実のところ困難である。AstaReal 社は, ヘマトコッカスの商業培養を行う中では, 世界で唯一, 一貫した屋内密閉式培養の生産様式を採用しており, 衛 生管理面はもとより, 変動する屋外環境の影響を受けな いため，常に一定の最適製造条件を保つことが可能であ り, 品質の安定性および製造効率という面でも高い優位 性がある。また富士化学グループは, アスタキサンチン の国内サプライヤーとしては唯一，原料となるへマト コッカス藻の培養から, アスタキサンチンの抽出, さら には粉末化などの製歳加工から販売まで，一貫して自社 グループ内で行っており万全のトレーサビリティを有し ている。富士化学グループのアスタキサンチンの品質は 国際的にも認められており, 米USPによって策定され た「へマトコッカス由来のアスタキサンチン」の品質規 格でも, 標準規格として採用されているほか ${ }^{4,5)}$, 豊富 な安全性デー夕を備えている ${ }^{6,7)}$ などのことから米国で GRAS 認定もされている。

\section{3 アスタキサンチンの生理活性}

\section{$3 \cdot 1$ 一重項酸素 $\left({ }^{1} \mathrm{O}_{2}\right)$ 消去活性作用, 脂質過酸化抑 制作用}

アスタキサンチンは，70 年以上も前に単離されてい るが, 魚介に多く認められる“単なる”色素ではないこ とが明らかになったのは, 意外なことに 1980 年代に入っ てからのことで, 強い脂質過酸化抑制作用や一重項酸素 $\left({ }^{1} \mathrm{O}_{2}\right)$ 消去活性が相次いで報告された。2012 年 5 月現 在では, アスタキサンチンに関する論文は, PubMed で 検索できるもので約 900 報に上り, 近年では, アスタキ サンチンの生理活性に関する論文数が特に増加傾向であ る。それら論文での機序として, 最も考え得るのが, そ の優れた抗酸化活性に基づくものである。

アスタキサンチンをはじめとするカロテノイド類は, 活性酸素である ${ }^{1} \mathrm{O}_{2}$ のエネルギーをそのポリエン部分の 長大な共役二重結合との相互作用により受け取り, カロ テノイドは過剰なエネルギーを熱として放散し, 基底状 態の三重項酸素 ${ }^{3} \mathrm{O}_{2}$ （通常の酸素分子）に戻すという， 自身の酸化物を生じない物理的なクエンチン機構により 非常に強い消去活性を示す。著者らは, アスタキサンチ 
ンをはじめとするカロテノイド類や市販で流通するポリ フェノールや抗酸化ビタミンなどを同一条件下で抗酸化 活性を評価したところ，既報の通り，カロテノイド類が 極めて高い活性を示し， カロテノイド類の多くは周囲の 溶媒極性などによって活性が大きく変化するが，アス夕 キサンチンはその変化は小さく, 広い環境で機能すると

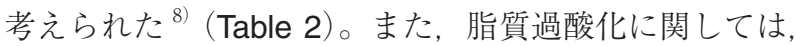
Miki らが, ラット肝臓ミトコンドリアをモール塩によ り自動酸化させたところ， $\alpha$-トコフェロールと比較し てアスタキサンチンは脂質の過酸化物（LOOH）の蓄積 を顕著に抑制することを示すことを報告 ${ }^{3}$ したのをは じめ,リポソームなどの膜脂質や LDLの過酸化を強く 抑制する報告 ${ }^{9)}$ などが多数存在する。

また，アスタキサンチンの抗酸化物質としての有利な 点として、“プロオキシダント活性”が低いことがある。 プロオキシダント活性とは, 抗酸化物自身が, 濃度や環 境などによって，抗酸化物質として機能せず，かえって 周りの物質を酸化する作用であり，例えば，ビタミン C であるアスコルビン酸は，過酸化水素に対して非常に強 い抗酸化活性を示すが, 濃度や金属イオンの介在などで, 過酸化物を形成することがあるということが報告されて いる ${ }^{10)}$ 。トコフェロールやポリフェノール類も同様の
報告が複数存在する ${ }^{11)}$ 。カロテノイド類で見ると，低 酸素分圧下では, カロテノイドはカロテン類もキサント フィル類もともに非常に強い活性を示すが，前者は，高 酸素分圧下では，抗酸化物質としてよりもむしろプロオ キシダントとして機能する。しかしながら，後者は，そ の活性が低く，高酸素分圧下でも抗酸化活性を発揮でき る。なかでも，一般的な食品に含まれるカロテノイドの うち，アスタキサンチンが最もプロオキシダント活性が 低いことが報告されている ${ }^{12)}$ 。興味深い報告として, 様々 なカロテノイドを含んだ生体膜に近い環境のリン脂質膜 の過酸化を評価したところ，カロテン類に属するものよ りキサントフィルのほうがプロオキシダントになりにく く，中でもアスタキサンチンが実験内で最もその活性が 強いことが報告されている ${ }^{13)}$

以上のように，複数のグループの報告から，アスタキ サンチンは生体膜環境において, 非常に強い抗酸化活性 を有しつつ, さらに, 自身のプロオキシダント活性は低 いという，生体にとって非常に都合の良い抗酸化物質で あると考えられる。

\section{3・2 アスタキサンチンの生体への作用}

前述したようにアスタキサンチンは優れた ${ }^{1} \mathrm{O}_{2}$ 消去活 性を示す。 ${ }^{1} \mathrm{O}_{2}$ は, その高い反応性から様々な生体組織

Table 2 各種抗酸化物質の一重項酸素消去活性*

\begin{tabular}{|c|c|c|c|}
\hline \multirow{2}{*}{ 化合物名 } & \multicolumn{3}{|c|}{$k_{T}\left(10^{6} \mathrm{M}^{-1} \mathrm{~s}^{-1}\right)$} \\
\hline & $\mathrm{CDCl} 3$ & $\mathrm{CDCl} 3 / \mathrm{CD} 3 \mathrm{OD} \quad(2: 1)$ & $\mathrm{DMF} / \mathrm{CDCl} 3(9: 1)$ \\
\hline Astaxanthin & 2200 & 1800 & 5400 \\
\hline Canthaxanthin & 2200 & 1300 & 2000 \\
\hline$\alpha$-Carotene & 660 & 230 & 930 \\
\hline$\beta$-Carotene & 2200 & 280 & 1100 \\
\hline$\beta$-Cryptoxanthin & 2000 & 270 & 1700 \\
\hline Fucoxanthin & 290 & 75 & 970 \\
\hline Lycopene & 3000 & 1400 & 3400 \\
\hline Lutein & 610 & 260 & 2100 \\
\hline Zeaxanthin & 2000 & 730 & 3400 \\
\hline L-Ascorbic acid & - & - & 0.89 \\
\hline$\alpha$-Tocopherol & 20 & 3.9 & 49 \\
\hline$\alpha$-Lipoic acid & 56 & 38 & 72 \\
\hline Ubiquione 10 & 1.9 & 2.1 & 6.8 \\
\hline Curcumin I & - & - & 3.6 \\
\hline (-)-Epigallocatechin gallate & - & - & 9.6 \\
\hline Quercetin & - & - & 1.8 \\
\hline Resveratrol & - & - & 1.2 \\
\hline Probucol & - & - & 0.44 \\
\hline Edaravon & - & - & 6.7 \\
\hline Trolox & - & - & 11 \\
\hline
\end{tabular}

*文献 8 より引用および改変。 
や生体分子に酸化損傷を与え得るが，特に，常に可視光 や紫外光に曝される皮膚組織は, ${ }^{1} \mathrm{O}_{2}$ 産生による直接的 な酸化的損傷を受けることになる。例えば, 皮膚表面では, アクネ菌の代謝産物であるコプロポルフィリンの光増感 作用により ${ }^{1} \mathrm{O}_{2}$ の産生が起こる事が報告されている ${ }^{13)}$ 。 また，長期間繰り返し浴びる紫外線が原因の光老化によ るシワの形成には，皮膚真皮層で発生する ${ }^{1} \mathrm{O}_{2}$ が関与す ると言われている。 ${ }^{1} \mathrm{O}_{2}$ は, カロテノイド以外の一般的 な抗酸化物質での消去は低度であるため, 皮膚組織は光 による直接的な酸化ストレスにつねに暴露されることに なる。アスタキサンチンの光老化に対する作用は多く報 告されて扔り，アスタキサンチンは，コプロポリフィリ ンによる皮脂の過酸化を抑制する ${ }^{14)}$ 。また，ヒ卜皮膚 線維芽細胞の ${ }^{1} \mathrm{O}_{2}$ による細胞への酸化的障害を評価した ところ，アスタキサンチンは他の一般的な抗酸化物質と 比較して, 非常に強い細胞保護効果があることが示され ている ${ }^{15)}$ 。ヒトでの試験に扔いても,多くの報告があり, 特にシワの項目で改善効果が示されている ${ }^{16,17) 。 ~}$

生活習慣病（糖尿病，心疾患，脳疾患など）と一般的 に認知される様々な慢性疾患の原因や発症への進展は, 高血糖, 脂質代謝異常, 高血圧がそれぞれ複雑に関連し ながら強く関与している。それらは，いわゆる内臟脂肪 型肥満が大きな要因であり, 内臟脂肪型肥満とそれらの 因子が合併した場合, 前述した重大な疾病リスクが格段 に高まることから, 近年, そのような代謝異常状態をメ タボリックシンドロームと呼ぶ病態の概念が定着してき た。

メタボリックシンドロームの上流部には，インスリン が効きにくい，いわゆるインスリン抵抗性と呼ばれる現 象が生じる。インスリン抵抗性は, 多くの原因があるが, 端的に述べると食事に由来の慢性的な高血糖や高脂肪食 による過栄養に伴い, 内臟脂肪組織や肝臟組織などから 分泌される遊離脂肪酸や炎症性サイトカインなどによっ て，ミトコンドリアや小胞体（ER）ストレスや慢性的 な炎症の惹起に付随する複合的な要素によって生じる (Fig. 4)。さらに，それらの根本には酸化ストレスが大 きくかかわっており，インスリン抵抗性は，抗酸化物質 で部分的に解除できることが近年報告されてきた ${ }^{18)}$ 。 我々は, アスタキサンチンが, 骨格筋細胞モデルにおい て，インスリンシグナリングにおける IRS-1/PI3K/PKB （Akt）の作用増強により, 糖取り込みに関連するイン スリンの効きをよくすることを報告し，また，遊離脂肪 酸や炎症性サイトカインなど, 活性酸素種による酸化ス トレスが係る様々な要因によるインスリン抵抗性モデル に扔いて，インスリン抵抗性の軽隇効果も報告した ${ }^{19)}$ 。 同様に太田らのグループは，C57BL/6 マウスに抢ける

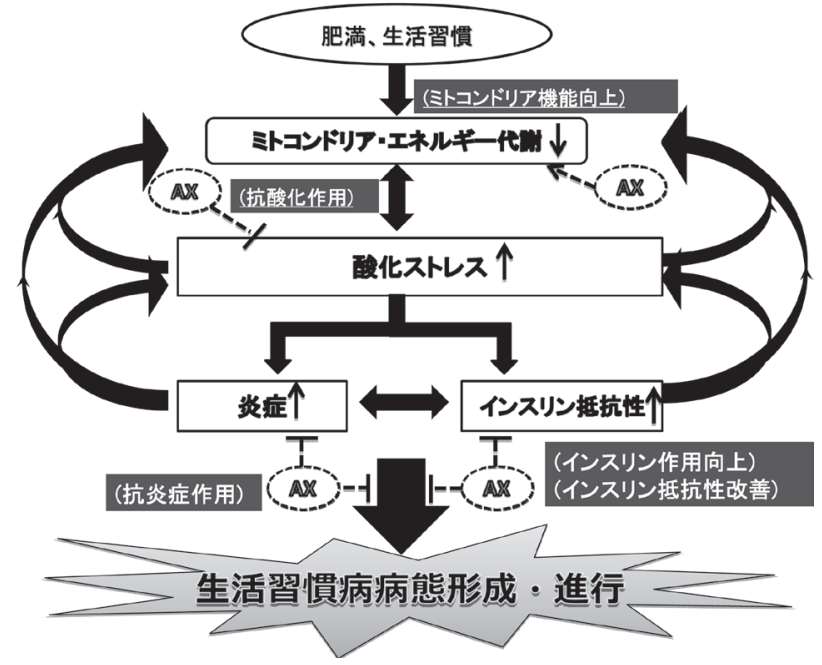

Fig. 4 生活習慣病に対するアスタキサンチンの作用。肥満 や生活習慣による過剩エネルギーにより, 酸化ス卜 レス状態になり, インスリン抵抗性や炎症を惹起さ れる。これらは相互の増悪し合い, 更にミトコンド リアなどへ障害を促進し, このサイクルは増悪され ていく。生体の防御機構が破綻した際, 生活習慣病 が発症する。予想される AXの期待される効果とし て AXのミトコンドリア機能向上, 抗酸化効果, イ ンスリン抵抗性改善, 抗炎症作用が挙げられ, それ らの作用により生活習慣病の発症進展を抑制するこ とが考えられる。

高コレステロール高脂肪食による lipotoxic NASH モデ ルに扔いて, アスタキサンチンの肝臟でのインスリン抵 抗性の改善効果を報告している ${ }^{20)}$

さらに興味深い報告として, アスタキサンチンは, 細 胞内では, 膜構造であるミトコンドリアに比較的集積し やすく ${ }^{21,22) ， ア ス タ キ サ ン チ ン の 大 き な タ ー ケ ゙ ッ ト の ~}$ 一つにミトコンドリアが考えられる。インスリン抵抗性 は，上記のように酸化ストレスが大きく関与しており， ミトコンドリアは, TCA 回路, 酸化的リン酸化や脂肪 酸の $\beta$ 酸化など細胞のエネルギー代謝の要であること は周知であるが, 前述のような高栄養状態や酸化ストレ スなどにさらされると, 時にその恒常性を逸脱し異常を もたらし, 余剩なエネルギーは活性酸素を産出に寄与し, 酸化ストレスの原因ともなり得る。ゆえに酸化ストレス の観点では, ミトコンドリアの機能性維持は非常に重要 な意味を持つ。アスタキサンチンは, 酸化ストレスによる ミトコンドリア膜電位の消失など機能低下に対しての抑 制作用も報告されており, ミトコンドリアの機能維持に重 要な役割を果たしている可能性が示唆されている ${ }^{23,}{ }^{24)}$ 。 また, Naitoらは，2 型糖尿病モデルマウスの腎糸球体 細胞に扔いて, ミトコンドリア電子伝達系酸化的リン酸 化に関与する遺伝子群の通常と異なるような発現㐫進を, アスタキサンチンが是正することも報告している ${ }^{25)}$ 。更 
に前述した Manabe らは腎糸球体のメザンギウム細胞 において，高血糖に対するアスタキサンチンの影響を見 たところ，高血糖メザンギウム細胞には，ミトコンドリ アタンパク質の一部が酸化修飾体である 4-hydroxy-2 nonenal 付加タンパク質として認められ，アスタキサン チンにより，それが抑制されることを示している ${ }^{21) 。 ~}$ また，Aoiらは，運動負荷マウスの骨格筋においてアス タキサンチンはミトコンドリアの酸化ストレスによる夕 ンパク質酸化修飾による障害からの保護作用を有し， $\beta$ 酸化を立進させる効果を報告している ${ }^{26)}$ 。以上のこと から，アスタキサンチンは，ミトコンドリアの機能性維 持，酸化ストレスによる障害の抑制に非常に強く機能す ると考えられる。

さらに興味深いことに，近年，脂質代謝に重要である 核内受容体 PPAR $\gamma$ の選択的調節因子として機能し得る ことが報告されている ${ }^{27)}$ 。

アスタキサンチンは, また，抗炎症作用に関してもい くつかの知見が知られている。例えば，マクロファージ 細胞モデルおよびマウスモデルにおいて，炎症を惹起す るリポ多糖（LPS）などによる前炎症プロセスである NF $\kappa \mathrm{B}$ の活性化を抑制することにより，下流の炎症性メ ディエーター（iNOSによるNO や PGE2）や炎症性サ イトカイン関連分子（TNF $\alpha, \operatorname{COX} 2$, IL1- $\beta$ ) の産生を 抑制することが報告されており ${ }^{28)}$ ，同様に，ラット LPS 誘導ブドウ膜炎モデルにおいては, 眼房水中の浸 潤細胞数, タンパク濃度, $\mathrm{NO}, \mathrm{TNF} \alpha, \mathrm{PGE} 2$ などの 炎症マーカーに対してアスタキサンチンは陽性対象の抗 炎症ステロイドと比較して遜色のない効果を示し, 虹彩・ 網様体において，NFאB の活性化（核内移行）を抑制し ていた ${ }^{29)}$ ささらに Kishimotoらは，ホルボールエステ ルによる THP1 マクロファージの活性化において，ア スタキサンチンは, 組織への浸潤に重要なマトリックス メタロプロテアーゼ（MMP）群の遺伝子発現抑制, 動 脈硬化に関与する酸化 LDL 受容体であるクラス A スカ ベンジャーレセプターや CD36 などの発現を抑制し，炎 症性サイトカインの発現も抑制していたことを報告して いる ${ }^{30)}$ 。以上のように炎症にかかわるマクロファージ の活性化組織浸潤の抑制の機序としては，やはり，それ らに関わる重要な因子である $\mathrm{NF} \kappa \mathrm{B}$ の活性化には活性 酸素が関与することから，活性酸素を消去する系がまず 考えられるが, PPAR $\gamma$ のアゴニストもマクロファージ において $\mathrm{NF} \kappa \mathrm{B}$ を抑制する作用を持つことも報告され ていることから，両者が協奏しあってより効率的に活性 を呈していると考えられる。

ここまでで示したように，アスタキサンチンは，抗酸 化能および付随する生理活性を介し，酸化ストレスを低
減することによって，メタボリックシンドロームに対抗 できる可能性が強く示唆される (Fig. 4)。

上記のような作用機序から， 実験動物 ${ }^{19-22,31-38)}$ やヒ 卜臨床試験 ${ }^{40-43)}$ においても多くのメタボリックシンド ロームに関連する高血圧, 血中脂質, インスリン抵抗性 などの改善, 動脈硬化抑制, あるいは, 非アルコール性 脂肪肝炎，糖尿病合併症予防などの報告が多くある。

以上のようにアスタキサンチンは，活性酸素種による 酸化ストレスが根本にかかわる疾病に強い効果が期待さ れる。ヘマトコッカス藻によるアスタキサンチンの安定 供給が可能になった現在では，アスタキサンチンの効果 に対する知見も年々大幅に増加傾向にあり，対象も In Vitroによる活性評価から, 詳細なメカニズム検討が主 体になりつつ, In Vivoである動物試験, さらにはヒト 臨床試験による効果評価などなどのステップの研究が数 多く行われつつある。本稿では，アスタキサンチンの有 用作用については，今後さらに明らかになるであろうメ タボリックシンドローム関連への有用作用を中心に記し たが，アスタキサンチンは，本稿でも少し触れた皮膚へ の有用作用や，眼精疲労 ${ }^{44)}$ に対する有用作用に関して ヒト臨床を含め幅広い研究がなされている。今後更なる 研究が期待される。

\section{文 献}

1) R. Kuhn, N. A. Sörensen, Angew. Chem., 51, 465-466 (1938)

2) T. Maoka, Mar Drugs, 9 (2), 278-293 (2011)

N. Misawa, Mar Drugs, 9 (5), 757-771 (2011)

3) W. Miki, Pure Appl. Chem., 63 (1), 141-146 (1991)

4) U. S. Pharmacopeia, Food Chemical Codex, 8th edition (2011), Astaxanthin esters from Haematococcus pluvialis.

5) U. S. Pharmacopeia, Dietary supplements standards, Astaxanthin esters from Haematococcus pluvialis.

6) 大神一浩, 白取謙治, 新田卓也, 新明康弘, 陳 進輝, 吉田和彦, 塚原寛樹, 大野重昭, 臨床医薬, 21, 651（2005）

7）塚原寛樹，福原育夫，竹原功，健康·栄養食品研究，8, 1 (2005)

8) Y. Nishida, E. Yamashita, W. Miki, Carotenoid Science, $11,16-20$ (2007)

9) T. Iwamoto, K. Hosoda, R. Hirano, H. Kurata, A. Matsumoto, W. Miki, M. Kamiyama, H. Itakura, S. Yamamoto, K. Kondo, J. Altheroscler thromb., 7, 216-212 (2000)

10) Y. Li, H. E. Schellhorn. J Nutr 137, 2171-2184（2007）

11) B. Halliwell, Arch Biochem Biophys. 476 (2). 107-12 (2008)

12) HD Martin, C Ruck, M Schmidt, S Sell, S. Beutner, B. Mayer and R. Walsh, Pure Appl. Chem., 71 (12), 22532262, (1999)

13) H. McNulty, R. F. Jacob, R. P. Mason, Am J Cardiol. 
101 (suppl), 20D-29D (2008)

14) K. Arakane, Carotenoid Science, 5, 21-24 (2002)

15）富永久美, 本江信子, 柄戸万理子, 山下栄次, Food Style 21, 13 (1), 84-86 (2009)

16）山下栄次, Food Style 21，11（9），32-34（2007）

17) K. Tominaga, N. Hongo, M. Karato, E. Yamashita, Acta Biochim Pol., 59 (1), 43-47 (2012)

18) N. Houstis, E. D. Rosen, E. S. Lander, Nature, 40 (7086), 944-948 (2006)

19）石木学, 西田康宏, 藤坂志帆, 岩田実, 薄井勲, 戸邊 一之, 糖尿病, Vol.55, Suppl.1, (第 55 回日本糖尿病学 会学術集会抄録集）p.S-303（2012）

20）倪銀華，永島田まゆみ，Lili Zhan，金子周一，太田嗣人, 糖尿病, Vol.55, Suppl.1, (第 55 回日本糖尿病学会学術 集会抄録集）p.S-167（2012）

21) E. Manabe, O. Handa, Y. Naito, K. Mizushima, S. Akagiri, S. Adachi, T. Takagi, S. Kokura, T. Maoka, T. Yoshikawa, J. Cell Biochem., 103 (6), 1925-1937 (2008)

22) J. S. Park, H. W. Kim, B. D. Mathison, M. G. Hayek, S. Massimino, G. A. Reinhart, B. P. Chew, Nutr. Metab., 7, 52. (2010)

23) A. M. Wolf, S. Asoh H. Hiranuma, I. Ohsawa, K. Iio, A. Satou, M. Ishikura, S. Ohta, J. Nutr. Biochem., 21 (5), 381-389 (2010)

24) X. Liu, T. Shibata, S. Hisaka, T. Osawa., Brain Res., 1254, 18-27 (2009)

25) Y. Naito, K. Uchiyama, K. Mizushima, M. Kuroda, S. Akagiri, T. Takagi, O. Handa, S. Kokura, N. Yoshida, H. Ichikawa, J. Takahashi, T. Yoshikawa., Int. J. Mol. Med., 18 (4), 685-95 (2006)

26) W. Aoi, Y. Naito, Y. Takanami, T. Ishii, Y. Kawai, S. Akagiri, Y. Kato, T. Osawa, T. Yoshikawa., Biochem. Biophys. Res. Commun., 366 (4), 892-897 (2008)

27) M. Inoue, A. Matsumoto, H. Tanabe, T. Ohno, K. Umegaki, J. Takahashi, The 15th International Symposium on Carotenoids. Okinawa Japan (2008)

28) S. J. Lee, S. K. Bai, K. S. Lee, S. Namkoong, H. J. Na, K. S. Ha, J. A. Han, S. V. Yim, K. Chang, Y. G. Kwon, S. K. Lee, Y. M. Kim. Mol. Cells. 16 (1), 97-105 (2003)

29) Y. Suzuki, K. Ohgami, K. Shiratori, X. H. Jin, I. Ilieva, Y. Koyama, K. Yazawa, K. Yoshida, S. Kase, S. Ohno.,
Exp. Eye Res., 82, 275-281 (2006)

30) Y. Kishimoto, M. Tani, H. Uto-Kond, M. Iizuka, E. Saita, H. Sone, H. Kurata, K. Kondo., Eur. J. Nutr., 49, 119-126 (2010)

31) G. Hussein, T. Nakagawa, H. Goto, Y. Shimada, K. Matsumoto, U. Sankawa, H. Watanabe., Life Sci., 80 (6), 522-529 (2007)

32) M. Ikeuchi, T. Koyama, J. Takahashi, K. Yazawa., Biosci. Biotechnol. Biochem., 71 (4), 893-899 (2007)

33) S. Akagiri, Y. Naito, H. Ichikawa, K. Mizushima, T. Takagi, O. Handa, S. Kokura, K. Iio, Y. Okada, M. Ishikura, T. Yoshikawa, J. Clin. Biochem. Nutr. 43. Suppl 1. 390-393 (2008)

34) H. G. Preuss, B. Echard, E. Yamashita, N. V. Perricone, Int. J. Med. Sci., 8, 126-38 (2011)

35) Y. Yang, J. M. Seo, A. Nguyen, T. X. Pham, H. J. Park, Y. Park, B. Kim, R. S. Bruno, J. Lee, Nutr., 141 (9), 16111617 (2011)

36) K. Uchiyama, Y. Naito, G. Hasegawa, N. Nakamura, J. Takahashi, T. Yoshikawa, Redox Rep., 7 (5), 290-293 (2002)

37) Z. W. Zhao, W. Cai, Y. L. Lin, Q. F. Lin, Q. Jiang, Z. Lin, L. L. Chen, Arzneimittelforschung, 61 (4), 239-246 (2011)

38) M. Nakano, A. Onodera, E. Saito, M. Tanabe, K. Yajima, J. Takahashi, V. C. Nguyen, J Nutr Sci Vitaminol, 54, 329-334 (2008)

39) J. Karppi, T. H. Rissanen, K. Nyyssönen, J. Kaikkonen, A. G. Olsson, S. Voutilainen, J. T. Salonen, Int. J. Vitam. Nutr. Res., 77 (1), 3-11 (2007)

40) M. Iwabayashi, N. Fujioka, K. Nomoto, R. Miyazaki, H. Takahashi, S. Hibino, Y. Takahashi, K. Nishikawa, M.Nishida, Y. Yonei, Anti-Aging Medicine 6 (4), 15-21 (2009)

41) A. Uchiyama, Y. Okada, J. Clin. Biochem. Nutr., 43, Suppl.1, 38-43 (2008)

42) J. Clin. Biochem. Nutr., 44 (3), 280-284. (2009)

43) H. Yoshida, H. Yanai, K. Ito, Y. Tomono, T. Koikeda, H. Tsukahara, N. Tada, Atherosclerosis, 209 (2), 520-523 (2010)

44）大木史郎, FOOD Style 21，14（1）, 45-47（2010） 